\title{
Prospects and Dimensions of Conflict Resolution Programs in the Islamic Context
}

Amr Abdalla (professor and vice rector, University for Peace, San Jose, Costa Rica) visited the International Institute of Islamic Thought (IIIT) on February 1,2013 , to discuss the challenges of conflict resolution and peace that has caught the attention of so many Muslim and non-Muslim scholars and policymakers for several decades. As the Muslim world remains plagued with violent confrontations between states and non-state actors, regional and national sectarian conflicts, and domestic conflicts with gender and family elements, such a discussion is very timely.

The outbreak of the Arab Spring, which has resulted in several Islamist groups taking power, has raised various questions: Why is it important to talk 
about conflict resolution and peace building in an Islamic context? How can the theoretical be combined with the practical? How does Islam fit into the demonstrations that occurred during the Arab Spring as well as into modernity? This is, according to Abdalla, the first opportunity that contemporary Muslims have had to answer these questions for themselves.

Abdalla pointed out several issues that have been problematical for Muslims. Among them are the fact that fiqh, which is human scholarship as opposed to revelation, has become overly legalistic and that different cultures have influenced the perception of Islam. To illustrate the second issue, he spent quite a bit of time on how Qur'an 12:20 (Sürah Yüsuf) has affected women: "And when [her husband] saw that his [Yusuf's] tunic was torn from behind, he said: 'Behold, this is [an instance] of your guile [kaydikunna], O womankind! Verily, awesome is your guile [kaydakunna]!"” According to him, many Muslims believe that kaydakunna is actually kaydakum and thus apply the verse to all women for all time, instead of to just those women who were present.

He then launched into an analysis of conflict based upon Q. 2:190: "And fight in God's cause against those who wage war against you, but do not commit aggression, for verily God does not love aggressors." Out of this verse he extracted four elements that deal with conflict: the situation/condition, the ruling, the manner by which the Muslim is to fight, and accountability. He said the scholars and their works traditionally focused on the ruling and largely ignored the manner in which the Muslim was to fight.

Following this he shifted to the domestic sphere. Citing Qur'an 2:22642 , he remarked that all but two of these verses related to divorce, family disputes, custody, alimony, and similar matters. Right in the middle, Q. 2:238, which calls upon Muslims to maintain their mid-day prayer, indicates that they should calm down, step back, take a prayer break, and then reengage with the other party.

In the case of divorce, he asked the audience how the principles of $m a$ ' $r \bar{u} f$ and $i h ̣$ ăn should be defined. Claiming that scholars did not pay enough attention to these terms, he presented his own definition: Ihṣān means "highest respect, dignity," while ma 'rüf means "shared knowledge that has become a traditional practice" or, in other words, "how you share kindness." The issue then becomes how one is going to act upon these concepts and thereby avoid escalating the matter. While classical scholars called upon Muslims to obey the rulings, Abdalla says that we need to exercise self-control so that we can deal respectfully with everyone involved in order to achieve the best result possible. 
He then listed four levels of conflict: value parameters ("red lines," such as no alcohol, adultery, and gambling), juristic matters (e.g., inheritance, divorce, custody, and other fiqhi issues), cultural issues (e.g., confusing culture with religion, such as forced arranged marriages), and needs and interests (that which has no specific religious ruling and so is open to negotiation and mediation). As this last category is the largest area of conflict, the involved parties need to stop saying "we have our own way" and remain open to all of the relevant literature and scholarship. While there are certain issues on which one does not comprise, no group has the right to force its views upon another.

He closed with several points: (1) realizing that peace and conflict resolution are universal (as opposed to "Islamic") concepts can help Muslims become more effective because they cannot reject others; (2) studying how modern scholarship on peace and conflict resolution approaches can be of some help; and (3) existing cultural variations on peace and conflict resolution approaches mean that there is no one "correct" way and that mutual understanding is necessary.

However, he pointed out that Islam's emphasis on community, family, and adherence to the "way of Allah" dictates that its models of conflict resolution and peacemaking respond to such values. Thus the models formulated by Muslims will depart, to one degree or another, from the dominant models found in the West, all of which have a strong interest-based and individualistic underpinning.

Several issues were discussed during the question and answer session: the meaning of "prepare your horses" (the importance of context); "God will tell you the truth of your dispute" (Q. 31:15; creates a space for coexistence); values change because of material development ("red-lines" can change); issues must be analyzed from an Islamic perspectives so that they can be made applicable today; and the entire context of the conflict must be analyzed (viz., what were the viewpoints and the lessons learned?), because legalism cannot produce this type of knowledge.

In conclusion, twenty-first-century Islamic scholarship must recognize the shortcomings of existing scholarship due to its historical and cultural limitations. As such, models of conflict resolution and peacemaking in an Islamic context must represent the strong adherence and attachment to Islamic principles and the maqāṣid al-sharì 'ah without reinforcing history- and culturespecific models.

Jay Willoughby

AJISS

Herndon, VA 